\title{
Literature Review: Penerapan Pendidikan Kesehatan untuk Meningkatkan Pengetahuan Remaja Putri tentang SADARI
}

\author{
Tuti Purwaningsih ${ }^{1 *}$ Isyti'aroh $^{2}$ \\ 1,2 Diploma Tiga Keperawatan, Universitas Muhammadiyah Pekajangan Pekalongan, Indonesia \\ *email: fikes.umpp@gmail.com
}

\begin{abstract}
Breast cancer is recently common to be suffered by young women. However, Breast Cancer has a greater chance to be cured if it is detected early, for instance by implementing Breast Self-Examination (BSE). Breast Self-Examination is a method to detect breast abnormalities early. BSE can be introduced through health education. The purpose of this study was to determine the improvement of young women understanding of BSE after joining health education based on a literature review. This literature review was constructed by analyzing 3 articles taken from Google Scholar with "BSE", "health education", and "understanding" as the keywords, and published during 2013-2020. Inclusion criteria the form of fulltext articles, quasy experiment or experiment, same test result. The results analysis number of respondents from the three articles 226 . The results showed that before to conduct health education the respondent's less understanding $38 \%$ and after to conduct health education the respondent's understanding $79 \%$. In conclusion, health education could be conducted to improve the understanding of BSE among young women. Therefore, health care providers are expected to conduct health education to improve the understanding of BSE, in young women.
\end{abstract}

Keywords: Health education; understanding; BSE

\begin{abstract}
Abstrak
Kanker payudara mulai menyerang remaja putri. Kanker payudara memiliki peluang besar sembuh jika dideteksi secara dini yaitu melalui pemeriksaan payudara sendiri (SADARI). Pemeriksaan payudara sendiri adalah cara untuk mengetahui secara dini kelainan pada payudara. Pendidikan kesehatan menjadi salah satu upaya meningkatkan pengetahuan SADARI. Tujuan karya tulis ilmiah ini untuk mengetahui peningkatan pengetahuan remaja putri setelah diberikan pendidikan kesehatan tentang SADARI berdasarkan literature review. Pendekatan dari metode penelitian yang digunakan adalah literature review dengan jumlah artikel tiga, diambil dari google scholar dengan kata kunci "SADARI", "pendidikan kesehatan", "pengetahuan", ketiga artikel terbit tahun 2013-2020. Kriteria inklusi adalah artikel fullteks, quasi eksperimen atau eksperimen, uji hasil sama. Hasil analisa jumlah responden dari tiga artikel 226. Hasil menunjukkan bahwa sebelum diberikan pendidikan kesehatan responden dengan pengetahuan kurang $38 \%$ dan setelah diberikan pendidikan kesehatan responden dengan pengetahuan baik $79 \%$, dapat disimpulkan bahwa pendidikan kesehatan dapat meningkatkan pengetahuan remaja putri tentang SADARI. Saran bagi pelayanan kesehatan hendaknya memberikan edukasi SADARI untuk meningkatkan pengetahuan SADARI pada remaja putri.
\end{abstract}

Kata kunci: Pendidikan kesehatan; pengetahuan; SADARI

\section{Pendahuluan}

Pemeriksaan payudara sendiri (SADARI) adalah cara untuk mengetahui sejak dini keabnormalan pada payudara. Pemeriksaan payudara sendiri yang dilakukan secara teratur merupakan suatu langkah penting sebagai upaya untuk mengetahui secara 


\section{Prosiding Seminar Nasional Kesehatan $\mathbf{2 0 2 1}$ Lembaga Penelitian dan Pengabdian Masyarakat Universitas Muhammadiyah Pekajangan Pekalongan}

awal kanker payudara [1]. Penyakit kanker payudara berada di nomor dua setelah penyakit kanker leher rahim. Kanker ini memiliki peluang besar untuk sembuh jika dideteksi secara dini. Salah satunya dengan SADARI yang dilakukan oleh diri sendiri [2].

Berdasarkan data International Agency for Research on Cancer (IARC) tahun 2018 menunjukkan bahwa di dunia angka tertinggi kanker pada laki laki menempati kanker paru-paru yaitu sebesar 40,4 per 100.000 jiwa. Sedangkan pada perempuan, angka tertinggi menempati kanker payudara yaitu sebesar 54,4 per 100.000 jiwa [3]. Data Riskesdas tahun 2018, di Indonesia pada tahun 2013 prevalensi tumor atau kanker mengalami peningkatan dari 1,4 per 1000 jiwa menjadi 1,79 per 1000 jiwa pada tahun 2018. Angka kejadian tertinggi terdapat di provinsi Yogyakarta yaitu 4,86 per 1000 jiwa, Sumatra Barat yaitu 2,47 per 1000 jiwa dan Gorontalo yaitu 2,44 per 1000 jiwa [4]. Di provinsi Jawa Tengah pada tahun 2019 tumor atau benjolan pada payudara ditemukan ada 702 orang [5]. Dinas Kesehatan Kabupaten Pekalongan tahun 2018 memaparkan terdapat 211 kejadian kanker payudara. Kanker payudara lebih banyak empat kali lipat dari kanker serviks yang terdapat 52 kejadian [6].

American Cancer Society menyarankan SADARI perlu dilakukan oleh perempuan yang berumur 20 tahun atau 20 tahun ke atas setiap bulan sesudah selesai haid (hari ke-7 atau ke-10), namun saat ini penyakit kanker payudara mulai menyerang pada perempuan usia muda. Oleh karena itu, usia remaja juga perlu melakukan SADARI untuk mengetahui secara dini kelainan pada payudara [7]. Remaja adalah masa perubahan dari masa anak-anak ke masa dewasa. Pada remaja terjadi perubahan fisik dan biologis. Perubahan fisik seperti payudara membesar [8].

Pengetahuan adalah hasil tahu dari sesudah seseorang menggunakan indra yang dimilikinya terhadap suatu kejadian. Pengetahuan manusia sebagian besar didapatkan melalui indra penglihatan (mata) dan indra pendengaran (telinga) [9]. Hasil penelitian yang dilakukan oleh Heriyanti, Arisdiani dan Widyastuti (2018) menjelaskan bahwa sebagian besar remaja putri belum mengetahui SADARI, alasan tidak melakukan SADARI yaitu karena sibuk dengan tugas-tugas di sekolah, ada yang mengatakan baru mendengar istilah SADARI dan banyak yang tidak tahu cara melakukan SADARI [10]. Kurangnya pengetahuan tentang penyakit kanker payudara dan deteksi dini kanker payudara menyebabkan tidak sedikit remaja putri menjadi kurang minat terhadap upaya deteksi dini kanker payudara. Pendidikan kesehatan menjadi salah satu upaya untuk meningkatkan pengetahuan mengenai SADARI [11].

Pendidikan kesehatan adalah suatu proses belajar pada individu, kelompok atau masyarakat yang mana didalam pendidikan tersebut terjadi proses pertumbuhan dan perkembangan atau berubah menjadi lebih baik. Pendidikan kesehatan dapat menjadikan individu, kelompok atau masyarakat sadar, tahu, mau dan mampu dalam menangani masalah kesehatan. Pengetahuan dapat diperoleh dari pengalaman atau kegiatan, seperti pendidikan kesehatan [12]. Informasi yang diberikan melalui pendidikan kesehatan menjadikan remaja akan lebih mengetahui tentang SADARI dan mau melakukan SADARI, sehingga remaja putri dapat menemukan benjolan atau kelainan pada payudara sejak dini. 


\section{Prosiding Seminar Nasional Kesehatan 2021 Lembaga Penelitian dan Pengabdian Masyarakat Universitas Muhammadiyah Pekajangan Pekalongan}

Hasil penelitian yang dilakukan oleh Pratiwi, Ariani, dan Karina (2017) menunjukan bahwa remaja putri sebelum diberikan pendidikan kesehatan mengenai SADARI memiliki pengetahuan kurang yaitu 42 responden, pengetahuan cukup 50 responden, pengetahuan baik 20 responden dan setelah diberikan pendidikan kesehatan remaja putri yang memilki pengetahuan kurang yaitu 2 responden, pengetahuan cukup 14 responden, pengetahuan baik 96 responden. Hal tersebut menunjukan bahwa terdapat hubungan pendidikan kesehatan dengan pengetahuan remaja putri mengenai SADARI [13]. Penelitian lain oleh Alam dan Subhan (2019) menunjukan bahwa remaja putri yang memiliki pengetahuan kurang mengenai SADARI sebelum diberikan pendidikan kesehatan yaitu 16 responden, pengetahuan baik 14 responden dan setelah diberikan pendidikan kesehatan remaja putri yang memiliki pengetahuan kurang yaitu 0 responden, pengetahuan baik 30 responden. Hasil penelitian tersebut menunjukkan bahwa terdapat hubungan pendidikan kesehatan dengan pengetahuan remaja putri mengenai SADARI [14].

\section{Metode}

Metode ekstraksi data dilakukan dengan mencari artikel jurnal sejumlah tiga dengan topik yang sama. Pendekatan dari metode penelitian yang digunakan adalah literature review. Artikel diambil dari laman pencarian google scholar. Kata kunci pencarian artikel yaitu "SADARI", "pendidikan kesehatan", "pengetahuan". Artikel terbit di laman jurnal resmi dibuktikan dengan adanya ISSN, terbit 10 tahun terakhir, artikel fullteks. Hasil pencarian artikel diperoleh 5 artikel, dengan kriteria inkulusi menjadi 3 artikel. Kriteria inklusinya yaitu desain quasi eksperimen atau eksperimen yang mampu diterapkan sebagai tindakan keperawatan, uji hasil menggunakan uji yang sama pada ketiga artikel, instrumen penelitian menggunakan kuesioner, ketiga artikel yang digunakan untuk penilaian pengetahuan menggunakan data kategorik (baik, cukup, kurang).

\section{Hasil dan Pembahasan Hasil}

Analisis Univariat

Hasil dari analisa distribusi frekuensi data demografi ketiga artikel adalah sebagai berikut :

Tabel 1. Distribusi Frekuensi Responden Berdasarkan Karakteristik Demografi

\begin{tabular}{|c|c|c|c|}
\hline Artikel & Karakteristik Demografi & Frekuensi & Presentase (\%) \\
\hline $\begin{array}{l}\text { I Dewa Ayu Suatina, } \\
\text { S.H.R. Ticoalu, Franly } \\
\text { Onibala (2013), Novaria }\end{array}$ & Umur & $(n=226)$ & \\
\hline Wijayanti, Triyanta, Nur & 15 tahun & 56 & 25 \\
\hline Ani (2019), Yulianti & 16 tahun & 79 & 35 \\
\hline $\begin{array}{l}\text { Anhar, Melly, Masnun } \\
\text { (2020) }\end{array}$ & 17 tahun & 91 & 40 \\
\hline
\end{tabular}




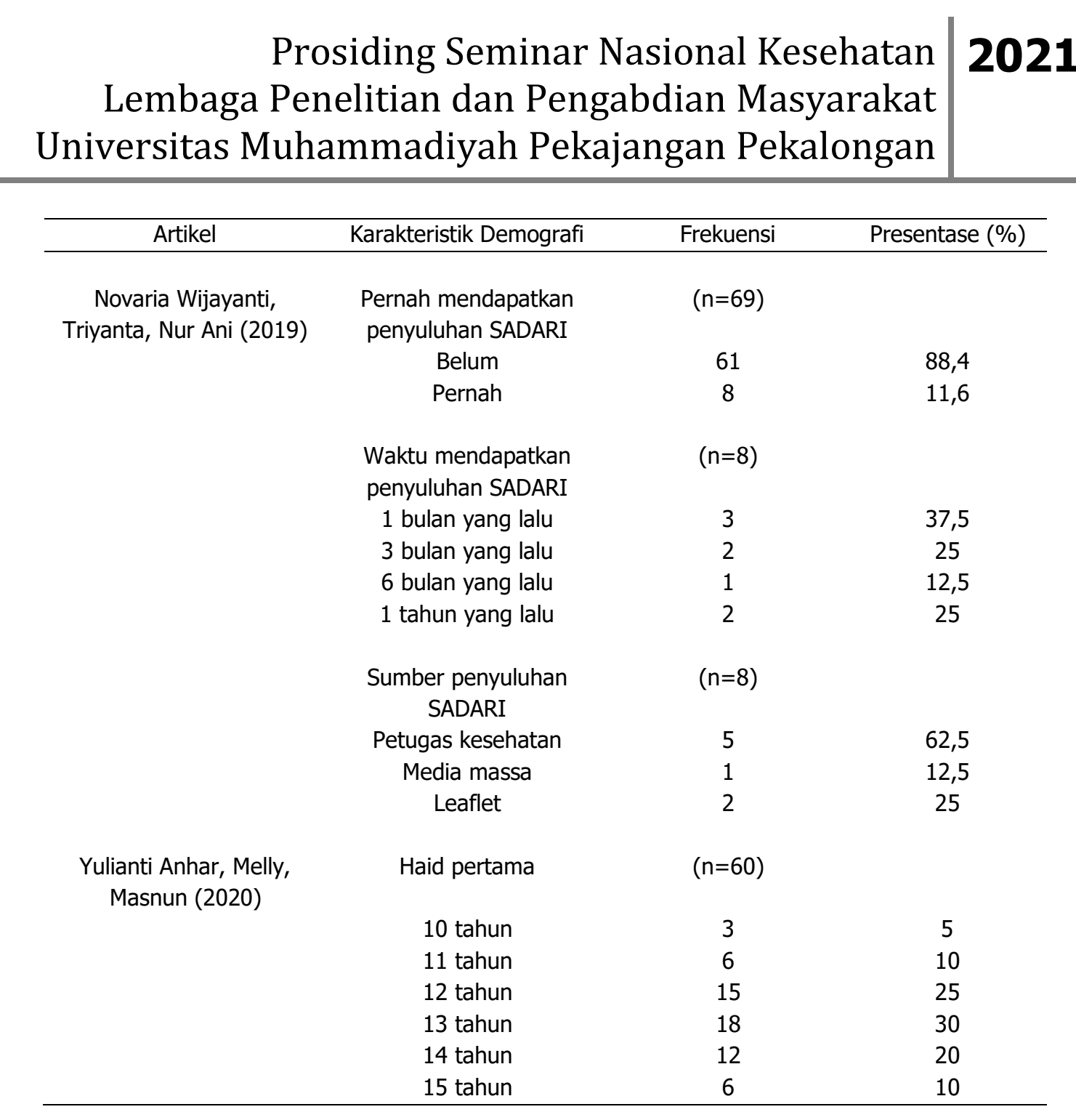

Tabel 1. menunjukkan bahwa sebagian besar responden adalah berusia 17 tahun sebanyak 91 orang (40\%). Pada artikel 2, dilihat dari pernah atau belum mendapatkan pendidikan kesehatan SADARI, sebagian besar responden belum pernah mendapatkan pendidikan kesehatan SADARI yaitu sebanyak 61 orang $(88,4 \%)$ dan hanya 8 orang $(11,6 \%)$ yang pernah mendapatkan pendidikan kesehatan SADARI. Dari 8 orang yang pernah mendapatkan pendidikan kesehatan SADARI sebagian besar waktu mendapatkan 1 bulan yang lalu yaitu sebanyak 3 orang $(4,3 \%)$. Sumber mendapatkan pendidikan kesehatan SADARI sebagian besar diperoleh dari petugas kesehatan yaitu sebanyak 5 orang (7,2\%). Pada artikel 3 diketahui bahwa sebagian besar haid pertama responden adalah pada umur 13 tahun sebanyak 18 orang (30\%).

Tabel 2. Distribusi Rata-rata Pengetahuan Responden Sebelum dan Sesudah

\begin{tabular}{ccccc}
\multicolumn{5}{c}{ Intervensi $(\mathrm{n}=226)$} \\
\hline Variabel & \multicolumn{2}{c}{ Sebelum intervensi } & \multicolumn{2}{c}{ Sesudah intervensi } \\
\cline { 2 - 5 } & $\mathrm{N}$ & $\%$ & $\mathrm{~N}$ & $\%$ \\
\hline Pengetahuan & & & & \\
Kurang & 85 & 38 & 11 & 5 \\
Cukup & 92 & 40 & 37 & 16 \\
Baik & 49 & 22 & 178 & 79 \\
\hline
\end{tabular}




\section{Prosiding Seminar Nasional Kesehatan Lembaga Penelitian dan Pengabdian Masyarakat Universitas Muhammadiyah Pekajangan Pekalongan}

Tabel 2. menunjukkan bahwa sebelum dilakukan pendidikan kesehatan tentang SADARI tingkat pengetahuan remaja putri dengan kategori baik sebanyak 49 orang (22\%) dan sesudah diberikan pendidikan kesehatan tentang SADARI pengetahuan remaja putri meningkat dengan kategori baik sebanyak 178 orang (79\%). Pengetahuan remaja putri dengan kategori cukup sebelum diberikan pendidikan kesehatan tentang SADARI sebanyak 92 orang (40\%) dan sesudah diberikan pendidikan kesehatan tentang SADARI pengetahuan remaja putri dengan kategori cukup sebanyak 37 orang (16\%). Pengetahuan remaja putri dengan kategori kurang sebelum diberikan pendidikan kesehatan tentang SADARI sebanyak 85 orang (38\%) dan sesudah diberikan pendidikan kesehatan tentang SADARI pengetahuan remaja putri dengan kategori kurang sebanyak 11 orang (5\%). Hal tersebut menunjukkan bahwa pendidikan kesehatan dapat meningkatkan pengetahuan remaja putri tentang SADARI.

\section{Pembahasan}

Pendidikan kesehatan adalah suatu upaya untuk menciptakan perilaku masyarakat yang aman dalam hal kesehatan. Pendidikan kesehatan diberikan agar masyarakat sadar dan tahu cara memelihara kesehatan, menghindari atau mencegah hal yang dapat merugikan kesehatan serta dapat memutuskan merawat jika sakit [15]. Pendidikan kesehatan menurut faktor predisposisi digunakan untuk menumbuhkan kesadaran, meningkatkan pengetahuan, perawatan, meningkatkan kesadaran, seperti penyuluhan kesehatan [16]. Pendidikan kesehatan menjadi salah satu upaya dalam meningkatkan pengetahuan mengenai SADARI. Karena, pengetahuan adalah hasil tahu seseorang yang diperoleh melalui inderanya terhadap hal tertentu. Sebagian besar pengetahuan diperoleh melalui indera penglihatan (mata) dan indera pendengaran (telinga). Pendidikan kesehatan melibatkan indera penglihatan dan indera pendengaran. Faktor yang mempengaruhi pengetahuan salah satunya adalah pendidikan. Tingkat pendidikan tidak hanya mempengaruhi pengetahuan, namun juga kemampuan dalam penerimaan informasi. Semakin tinggi pendidikan seseorang, semakin mudah dalam menerima informasi [17]. Ketiga artikel yang direview adalah remaja putri yang sedang sekolah SMA maupun SMK. Sedangkan pendidikan yang kurang dapat menghambat pengetahuan dan perkembangan sikap seseorang terhadap informasi yang diberikan. Selain itu faktor yang mempengaruhi tingkat pengetahuan adalah informasi. Penyampaian informasi dilakukan melalui pendidikan kesehatan [18]. Dengan diberikan pendidikan kesehatan seseorang akan mendapatkan informasi yang dapat diakses menjadi pengetahuan [19].

Ketiga artikel sama-sama menunjukkan hasil bahwa terdapat peningkatan pengetahuan remaja putri tentang SADARI sebelum diberikan pendidikan kesehatan dan sesudah diberikan pendidikan kesehatan. Ketiga artikel sama-sama dilakukan pada remaja. Remaja adalah masa peralihan dari masa anak-anak ke masa dewasa [20]. Faktor yang mempengaruhi tingkat pengetahuan salah satunya adalah umur, bertambahnya umur seseorang juga akan mengalami perubahan dalam aspek fisik dan mentalnya. Pengetahuan akan bertambah dan bervariatif sesuai dengan pengalaman seseorang [21]. Dengan diberikan pendidikan kesehatan maka seseorang 


\section{Prosiding Seminar Nasional Kesehatan Lembaga Penelitian dan Pengabdian Masyarakat Universitas Muhammadiyah Pekajangan Pekalongan}

akan mendapatkan pengalaman sehingga pengetahuan dapat bertambah dan meningkat. Semakin cukup umur, tingkat kematangan dan kekuatan seseorang dalam berfikir dan bertindak akan semakin baik [22]. Sebagian besar responden berumur 17 tahun, dimana umur tersebut adalah umur yang paling tinggi diantara karakteristik responden dalam ketiga artikel yang direview, sehingga pendidikan kesehatan yang diberikan dapat meningkatkan pengetahuan.

Peningkatan pengetahuan juga dapat dipengaruhi oleh faktor eksternal, salah satunya adalah media informasi. Pembelajaran dengan memberikan pendidikan kesehatan melalui media merupakan salah satu pembelajaran yang efektif, menarik dan menyenangkan. Media pembelajaran mempengaruhi keberhasilan dalam proses dan pencapaian hasil belajar yang baik [23]. Adapun perbedaan dari ketiga artikel yaitu dalam penggunaan media. Artikel satu menggunakan metode penyuluhan [24]. Penyuluhan memiliki fungsi untuk memberikan solusi pada masyarakat dalam memperoleh informasi mengenai pola hidup sehat dalam meningkatkan derajat kesehatan dan kesejahteraannya. Maka, fungsi penyuluh adalah menumbuhkan kesadaran kepada masyarakat agar dapat memenuhi kebutuhan tersebut atas kemauan dari diri sendiri. Tujuan penyuluhan dalam bidang kesehatan untuk menumbuhkan perubahan yang lebih terarah mengenai pola hidup bersih dan sehat. Perubahan tersebut diantaranya tingkat pengetahuan, sikap, tindakan, yang akan menjadikan masyarakat aktif, kreatif dan dinamis [25].

Perbedaan pada artikel dua yaitu menggunakan media video. Media pendidikan elektronik (media video) memiliki keuntungan yaitu melibatkan indera penglihatan dan pendengaran sehingga lebih mudah dimengerti, lebih menarik karena dengan suara dan gambar yang bergerak, tatap muka (langsung), pemutaran video dapat diatur, dapat diputar ulang dan jangkauan relatif besar. Media video dapat membuat responden lebih paham terhadap materi yang disampaikan, dapat merasakan emosi [26]. Alat bantu audiovisual adalah alat yang digunakan untuk merangsang indera pendengaran dan indera penglihatan, sehingga lebih mudah dalam menerima dan memahami informasi yang disampaikan oleh pendidik, contohnya adalah video, film [27].

Perbedaan pada artikel tiga, pendidikan kesehatan dilakukan menggunakan metode ceramah dan tanya jawab, media elektronik (powerpoint, microfon dan infokus), dan media cetak (leaflet). Metode ceramah adalah cara untuk menjelaskan suatu informasi atau pesan secara verbal, disertai dengan tanya jawab atau diskusi, kepada sekelompok responden dan dibantu dengan beberapa media yang dibutuhkan. Leaflet adalah bentuk penyampaian informasi atau pesan-pesan dengan selembar kertas yang dilipat yang terdiri dari beberapa halaman. Leaflet biasanya dipakai untuk pengingat dan bisa diberikan setelah selesai ceramah, diskusi atau pameran. Kelebihan leaflet yaitu dapat disimpan dalam waktu yang lama, lebih informatif, dapat digunakan sebagai keputusan atau referensi, jangkauan dapat lebih luas, satu lembar bisa dibaca oleh banyak orang dan pesan dapat yang bersifat intim atau pribadi [28]. Media elektronik yang digunakan adalah slide powerpoint. Slide dapat digunakan dalam penyampaian informasi atau pesan kesehatan [29]. Media video (audiovisual) melibatkan indera pendengaran dan indera penglihatan, sehingga lebih mudah 


\section{Prosiding Seminar Nasional Kesehatan 2021 Lembaga Penelitian dan Pengabdian Masyarakat Universitas Muhammadiyah Pekajangan Pekalongan}

seseorang dalam menerima dan memahami informasi. Studi menunjukkan bahwa $70 \%$ orang mengingat dari apa yang mereka dengar dan lihat [30].

Dari ketiga artikel, media dalam pemberian pendidikan kesehatan yang paling efektif adalah melalui media video. Informasi tentang SADARI dengan media video lebih mudah dimengerti karena dengan audio (lihat) dan visual (dengar) sehingga lebih jelas dalam memperlihatkan setiap tindakan atau cara melakukan SADARI. Penggunaan media video (audiovisual) melibatkan indera penglihatan dan indera pendengaran, sehingga lebih mudah seseorang menerima dan memahami informasi. Menurut para ahli, indera yang paling banyak menyampaikan pengetahuan ke dalam otak adalah mata. Kurang lebih $75 \%$ sampai $87 \%$ pengetahuan manusia didapatkan melalui mata. Sedangkan $13 \%$ sampai $25 \%$ lainnya didapatkan melalui indera yang lain. Sehingga alat-alat visual (lihat) lebih mudah dalam penyampaian dan penerimaan informasi atau pesan pendidikan [31].

Hal tersebut sejalan dengan hasil penelitian lain yang dilakukan oleh Rachman dan Putri (2020) dengan judul "Pengaruh Penyuluhan melalui Media Video terhadap Peningkatan Pengetahuan tentang Pemeriksaan Payudara Sendiri (SADARI) pada Siswi Kelas X di SMAN 8 Kendari", menunjukkan hasil bahwa sebelum diberikan pendidikan kesehatan tentang SADARI responden dengan pengetahuan kurang 29 orang $(60,4 \%)$ dan cukup 19 orang (39,6\%). Setelah diberikan pendidikan kesehatan responden dengan pengetahuan kurang 3 orang (6,2\%), dan cukup 45 orang (93,8\%). Peningkatan pengetahuan terjadi karena informasi yang diberikan oleh peneliti tersampaikan dengan baik sehingga terjadi peningkatan pengetahuan responden sebelum dan setelah diberikan pendidikan kesehatan. Pendidikan kesehatan dapat diberikan melalui berbagai macam media, salah satunya adalah media video. Media video menjadikan informasi yang diberikan tidak monoton dan tidak membosankan sehingga penerimaan informasi menjadi lebih baik. Hasil penelitian tersebut menujukkan bahwa pendidikan kesehatan dapat meningkatkan pengetahuan tentang SADARI [32].

\section{Kesimpulan}

Hasil analisa dari ketiga artikel dapat disimpulkan bahwa pendidikan kesehatan dapat meningkatkan pengetahuan remaja putri tentang pemeriksaan payudara sendiri (SADARI) yaitu sebelum diberikan pendidikan kesehatan responden dengan pengetahuan kurang $38 \%$ dan setelah diberikan pendidikan kesehatan responden dengan pengetahuan baik $79 \%$. Saran bagi pelayanan kesehatan hendaknya memberikan edukasi tentang pemeriksaan payudara sendiri (SADARI) untuk meningkatkan pengetahuan SADARI pada remaja putri.

\section{Ucapan Terima Kasih (jika ada)}

Penulis menyampaikan ucapan terima kasih kepada Rektor Universitas Muhammadiyah Pekajangan Pekalongan, Dekan Fakultas Ilmu Kesehatan Universitas Muhammadiyah Pekajangan Pekalongan, Kepala Program Studi Diploma Tiga Keperawatan Fakultas Ilmu Kesehatan Universitas Muhammadiyah Pekajangan Pekalongan, pembimbing 1 dan 2 yang telah memberikan bimbingan, segenap Civitas Akademika Universitas Muhammadiyah Pekajangan Pekalongan, orang tua yang selalu 


\section{Prosiding Seminar Nasional Kesehatan Lembaga Penelitian dan Pengabdian Masyarakat Universitas Muhammadiyah Pekajangan Pekalongan}

mendo'akan, memberikan semangat dan memotivasi, teman-teman satu angkatan Diploma Tiga Keperawatan Fakultas Ilmu Kesehatan Universitas Muhammadiyah Pekajangan Pekalongan yang membantu dan memberikan semangat.

\section{Referensi}

[1] Y. Olfah, N.K. Mendri, dan A. Badi'ah, Kanker Payudara dan Sadari. Yogyakarta : Nuha Medika, 2017.

[2] E. Purwoastuti dan E.S. Walyani, Panduan Materi Kesehatan Reproduksi dan Keluarga Berencana. Yogyakarta : Pustaka Baru Press, 2014.

[3] P.C. Wild, E. Weiderpass and B.W. Stewart, "World Cancer Report," International Agency for Research on Cancer, World Health Organization. Lyon, Perancis, 2020.

[4] Badan Penelitian dan Pengembangan Kesehatan Kementrian Kesehatan Republik Indonesia, Laporan Nasional Riset Kesehatan Dasar 2018. Jakarta, Indonesia : Departemen Kesehatan Republik Indonesia, 2018.

[5] Dinas Kesehatan Provinsi Jawa Tengah, Profil Kesehatan Provinsi Jawa Tengah. Semarang : Dinas Kesehatan Provinsi Jawa Tengah, 2019.

[6] Dinas Kesehatan Kabupaten Pekalongan, Profil Kesehatan Kabupaten Pekalongan 2019. Semarang : Dinas Kesehatan Kabupaten Pekalongan, 2019.

[7] U.L. Lubis, "Pengetahuan remaja putri tentang pemeriksaan payudara sendiri (SADARI)," Aisyah Jurnal IImu Kesehatan, vol. 2, no. 1, hh. 81-86, 2017.

[8] E. Kusmiran, Kesehatan Reproduksi Remaja dan Wanita. Jakarta Selatan : Salemba Medika, 2011.

[9] A. Agustini, Promosi Kesehatan. Yogyakarta : CV Budi Utama, 2010.

[10] E. Heriyanti, T. Arisdiani dan Y.P. Widyastuti, "Hubungan tingkat pengetahuan dan motivasi dengan tindakan pemeriksaan payudara sendiri (sadari) pada remaja putri," Community Of Publishing In Nursing, vol. 6, no. 3, Desember 2018.

[11] I. Swestivioka, I. Maulida dan N. Rahmanindar, "Perbandingan metode audio dan audio visual terhadap pengetahuan tentang pemeriksaan payudara sendiri (SADARI) pada remaja putri," The Southeast Journal Of Midwifery, vol. 5, no. 2, hh. 55-58, Oktober 2019.

[12] S. Fitriani, "Konsep dasar pendidikan kesehatan," dalam Promosi Kesehatan. Yogyakarta : Graha Ilmu, hh. 75-76, 2011.

[13] A. Pratiwi, S. Ariani, dan R. Karina, "Pendidikan kesehatan mengenai pemeriksaan payudara sendiri (sadari) terhadap nilai pengetahuan dan sikap remaja putri," Jurnal Kesehatan, vol. 7, no. 1, 2017.

[14] R.I. Alam dan Subhan, "Pengaruh pendidikan kesehatan terhadap tingkat pengetahuan tentang pemeriksaan payudara sendiri (sadari)," Bina Generasi Jurnal Kesehatan, vol. 1, 11 ed., 2019. 


\section{Prosiding Seminar Nasional Kesehatan 2021 Lembaga Penelitian dan Pengabdian Masyarakat Universitas Muhammadiyah Pekajangan Pekalongan}

[15] F.E.B. Setyawan, Pendekatan Pelayanan Kesehatan Dokter Keluarga (Pendekatan Holistik Komprehensif). Malang : Zifatama Jawara, 2019.

[16] A. Benih, Sosiologi Kesehatan. Yogyakarta : Nuha Medika, 2016.

[17] A. Wawan \& Dewi M., "Konsep pengetahuan," dalam Teori dan Pengukuran Pengetahuan, Sikap dan Perilaku Manusia. Yogyakarta : Nuha Medika, hh. 11-17, 2010.

[18] R.T.R. Lestari, I.G.A.S. Laksmi dan S.N.N. Sintari, "Pengaruh pendidikan kesehatan dengan media audio visual terhadap pengetahuan remaja putri tentang pemeriksaan payudara sendiri (SADARI)," British Medical Journal, vol. 6, no. 1, hh. 50-57, Juni 2019.

[19] Azwar dan Saifuddin, Sikap Manusia, Teori dan Pengukurannya. Jakarta : Pustaka Pelajar, 2011.

[20] N. Meilan, Maryanah dan W. Follona, Kesehatan Reproduksi Remaja Implementasi PKRR dalam Teman Sebaya. Malang : Wineka Media, 2018.

[21] W. Mubarak, Promosi Kesehatan untuk Kebidanan. Jakarta : Salemba Medika, 2012.

[22] A. Wawan \& Dewi M., "Konsep pengetahuan," dalam Teori dan Pengukuran Pengetahuan, Sikap dan Perilaku Manusia. Yogyakarta : Nuha Medika, hh. 17, 2010.

[23] E.T. Wulandari, A.N. Putra, D.M. Fitri dan F.K. Sari, "Efektivitas pendidikan kesehatan terhadap pengetahuan tentang pemeriksaan payudara sendiri (SADARI) pada siswi MA Al-Hamid tahun 2019," Kesehatan dan Kebidanan, vol. 8, no. 2, 2019.

[24] I.D.A.R. Suastina, S.H.R. Ticoalu, dan F. Onibala, "Pengaruh pendidikan kesehatan terhadap tingkat pengetahuan siswi tentang sadari sebagai deteksi dini kanker payudara di SMA Negeri 1 Manado," Ejournal Keperawatan, vol. 1, no. 1, Agust, 2013.

[25] Waryana, Promosi Kesehatan, Penyuluhan dan Pemberdayaan Masyarakat. Yogyakarta : Nuha Medika, 2016.

[26] N. Wijayanti, Triyanta dan N. Ani, "Efektivitas penyuluhan kesehatan sadari dengan media video terhadap pengetahuan pada remaja putri di SMK Muhammadiyah Cawas Klaten," Jurnal Ilmu Kesehatan Masyarakat Berkala, vol. 1, no. 1, 2019.

[27] Induniasih dan W. Ratna, Promosi Kesehatan. Yogyakarta : Pustaka Baru Press, 2017.

[28] A. Subargus, Promosi Kesehatan melalui Pendidikan Kesehatan Masyarakat. Yogyakarta : Gosyen Publishing, 2011.

[29] S. Fitriani, "Penyuluhan kesehatan," dalam Promosi Kesehatan. Yogyakarta : Graha Ilmu, hh. 180. 2011. 


\section{Prosiding Seminar Nasional Kesehatan 2021 Lembaga Penelitian dan Pengabdian Masyarakat Universitas Muhammadiyah Pekajangan Pekalongan}

[30] Y. Anhar, Melly dan Masnun, "Pengaruh penyuluhan kesehatan terhadap pengetahuan dan perilaku sadari pada remaja putri dalam pencegahan ca mammae di SMA Negeri 6 Pekanbaru," Husada Mahakam Jurnal Kesehatan, vol. 10, no. 2, hh. 145-155, November 2020.

[31] Syafrudin, Ilmu Kesehatan Masyarakat. Jakarta Timur : CV. Trans Info Media, 2015.

[32] W.O.N.N. Rachman dan Z.D. Putri, "Pengaruh penyuluhan melalui media video terhadap peningkatan pengetahuan tentang pemeriksaan payudara sendiri (SADARI) pada siswi kelas X di SMAN 8 Kendari," MIRACLE Journal Of Public Health, vol. 3, no. 2, Desember 2020. 